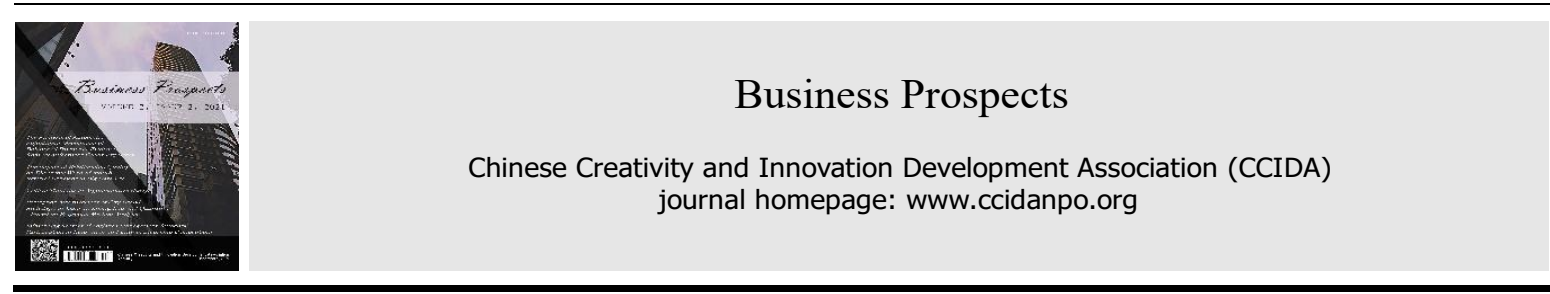

https://doi.org/10.52288/bp.27089851.2021.12.09

\title{
The Analysis of Automatic Adjustment Mechanism of Balance of Payments-Evidence from Manufactured Goods Exporters
}

\author{
Jia-Hua Yang ${ }^{1, *}$ and Grant G. L. Yang ${ }^{2}$ \\ ${ }^{1}$ School of International Business, Xiamen University Tan Kah Kee College \\ ${ }^{2}$ Associate Professor of School of International Business, Xiamen University Tan Kah Kee College \\ * Correspondence: lucy1871608@gmail.com
}

Received: 2021.07.03; Accepted: 2021.09.25; Published: 2021.12.01

\begin{abstract}
The balance of payments is the most scientific and complete record of international economic exchanges and transaction flows, and will be affected by interest rates, exchange rates, trade, finance, foreign exchange management and foreign investment. Studies related to balance of payment dominate in those increasingly open and developing economies, particularly for the manufactured goods exporters where manufacturing is the backbone, driver and display of modernization. This paper explores time trend analysis to analyze the automatic adjustment mechanism of balance of payments for manufactured goods exporters based on data from United Nations Conference on Trade and Development. The stability, cointegration, and causality tests are performed followed by multiple regression analysis that corporates one-period lagged and $\log$-formed models. The results are found to be consistent with theoretical analysis except for foreign direct investment. Granger causality tests demonstrate consumer price index and export are the causes of foreign direct investment, which might distort the explanation of foreign direct investment to balance of payment for manufactured goods exporters.
\end{abstract}

Keywords: Balance of Payments; Manufactured Goods Exporters; Automatic Adjustment Mechanism; Time Trend Analysis

\section{Introduction}

With the opening and the increasing dependence on foreign markets, the development of the world economy is inevitably affected by the world economy. How to balance domestic and foreign markets and maintain the stability of exchange rate and economy has become an important issue for all countries. As the key to domestic and foreign markets, exchange rates affect import and export trade as well as foreign direct investment and economic growth of any given country. Therefore, it is necessary to study in depth the relationship between exchange rates, foreign direct investment in import and export trade and the balance of payments, as well as economic growth (Hou, 2019). The development of economic globalization results in the globalization of industry and the prominence of manufacturing, especially high-end manufacturing, which is of great significance to a country in building a modern industrial system and enhancing international competitiveness (Han et al., 2021).

Balance of Payments (BOP) refers to all monetary payments and receipts of a country in a given period arising from external economic transactions and the settlement of external debts and liabilities. It is a microcosm of a country's external political and economic relations, and a reflection of a country's position in the world economy. Studies of BOP have been manifolded in terms of its comprehension and its treatment and their purpose have been to solve the emerging problems because of it in the economy (Ali et al., 2012). Theoretically, a country's BOP should be balanced in general. With the deepening of the process of opening, the structure of BOP may be different from that of the rest of the world for some countries. For example, China's current account and capital and financial accounts have a surplus at the same time, that is, the BOP structure of the "double 
surplus". China's BOP experienced its first "double surplus" in 1987 and lasted 13 years from 1999 to 2011 for as many as 21 times (Li, 2020). Yang and Lin (2021) have discussed the possibility of China's "double surplus" in BOP with binary choice models, and the results empirically show that China's BOP/GDP ratio and USDX can positively increase the probability of China's double surplus, while the effective exchange rate and FDI/GDP ratio act inversely.

The BOPs automatic adjustment mechanism is activated by the BOPs disequilibrium itself, without any government action, and operates until the disequilibrium is eliminated. The BOPs adjustments can be achieved through changes in national income aggregates, changes in relative price levels, or changes in both (Plessis, 1987). Such changes are not independent of each other, since changes in income aggregates can have secondary effects on relative price levels and vice versa. Under a system of fixed exchange rates, an analysis of BOPs policy centers around the search for methods that can be used to remove or alleviate a surplus or deficit in the BOPs that is due to more fundamental imbalances in the economy and that is therefore long-run in nature. Automatic adjustments can result from the relationship that exists between the state of the BOPs and the money supply in a country that maintains a fixed exchange rate. The change in the money supply resulting from a change in the state of the BOPs gives rise to three automatic corrective effects-namely, an interest rate effect, an income effect, and a price effect. Under the floating exchange rate system, the BOPs automatic adjustment mechanism is mainly reflected in the exchange rate adjustment mechanism, that is, the BOPs will cause changes in exchange rates, and through which the BOPs would be reconciled.

The methods of BOPs adjustment can be realized by adopting economic and administrative means to encourage exports, restrain imports and reduce the trade deficit. For example, fiscal tax cuts or export tax rebates can be used to stimulate exports. Demeaning the exchange rate of the local currency when the BOPs deficit is conducive to stimulating exports, curbing imports and improving the BOPs situation. Interest rates can also be adjusted to affect capital flow. The central bank, for example, can attract capital inflows and ease the BOPs deficit by raising the discount rate and driving up the market interest rate. Government credit and loans from international financial institutions can also adjust the BOPs imbalanced. Intergovernmental credit can be shortterm, i.e., short-term credit agreements between central banks of two or more countries to provide short-term loan support, or it can also be pre-arranged, i.e., "reciprocal credit agreements" between central banks to provide loan support when needed. Implement of foreign exchange management and direct administrative intervention in foreign exchange receipts and exchange rates are sometimes applied to improve the BOPs, such as the provision of foreign exchange earnings sold in whole or in large part to the state, and certain restriction on foreign exchange expenditure, etc. Since the BOPs is closely linked to the domestic economy, it is usually necessary to adopt corresponding policies on domestic economic policies in order to indirectly affect the BOPs. For example, domestic fiscal and bank austerity policies that reduce social demand can indirectly affect demand for foreign exchange expenditure. Researches of BOPs adjustment have been explored in West African (Connors, 1979), low developed countries (Bird, 1982; Paldam, 1990; Stoever, 2000), India (Ahluwalia, 1986), Central America (Bulmerthomas, 1987; Paldam, 1990), Eurozone (Micossi, 2016) and so on.

Foreign direct investment (FDI) is often considered to have greater significance in the international economy because of the effects of long-term strategy (Cazacu, 2016). On average, FDI has a significant longterm impact on the economy which is independent of the level of development (Hansen \& Rand, 2005). The impact of FDI on BOP has two opposing effects. On the one hand, FDI inflows tend to increase imports in the host country. On the other hand, the increase in national income due to FDI inflows may trigger more imports, thus negatively affecting BOP. FDI inflows can crowd in or crowd out domestic investment, depending on the circumstances (Chidoko and Sakuhun, 2015). In general, FDI has a positive impact on the economy, but it is not certain to what extent it does. A study on understanding the relationship between FDI and BOP in Pakistan suggested that FDI has a negative impact on birth taxes, possibly because FDI lead to an increase in imports (Ali et al., 2012).

A case study on the relationship between exports and imports and FDI in African countries found a positive impact of FDI on exports and imports (Hailu, 2010). Yabs (2018) examined the relationship between FDI and BOP in Kenya using descriptive and OLS regression analysis. The results demonstrated that FDI neither have any effect on exports nor on BOP. Alternatively, the author attributed this to the fact that FDI inflows are not large enough to have a significant impact on the balance of payments. Regarding the impact of FDI in Iran on the trade balance index, Hirad et al. (2013) used a multiple linear regression model to study it and found from it that the impact is positive and significant but the interest rate is relatively low. Also, the impact of FDI on Iran's non-oil exports is positive but insignificant.

Rahman (2016) found a two-way causal relationship between FDI and KAB in India through Granger 
causality tests. With the two shadowing each other, FDI is proved to be a very important macroeconomic variable for emerging economies. Gong (2019) found that FDI widens the BOP differential in both the cointegration equation and the error correction model, and that FDI has a persistent effect on the BOP differential. Yang et al. (2021) found that the changes in trade scale and current account balance are not sufficient to explain the short-term fluctuations of the effective exchange rate. Their study in China demonstrated that changes in effective exchange rate of RMB are also affected by the trend of the international leading currency (USD Index) and lag effects of statistical errors and omissions, meaning that flows of "hot money" may be one of the main factors leading to short-term fluctuations in the effective exchange rate of the RMB.

The article aims at analyzing the situation in the manufactured goods exporters with respect to the BOPs adjustment mechanism that should normally be at place. The manufactured goods exporters represent a combination of fixed or floating exchange rate, relatively low capital mobility and different monetary policies, and are thus exposed to the price and income adjustment processes as well as to their own fiscal policy impacts. For example, the Euro area membership internally represents a combination of the fixed exchange rate, capital mobility and no monetary policy autonomy; but externally, the Euro area countries apply floating exchange rates with high capital mobility, and autonomous monetary policy (Hnát and Jiránková, 2012). Therefore, Gross national product (GDP), inward foreign direct investment (FDI), consumer price index (CPI), real effective exchange rate (REER), exports (EX) and imports (IM) are selected to examine the impact on balance of payment (BOP). The effects of GDP, FDI, CPI, REER, EX and IM on the BOP of manufactured good exporters are investigated using data from UNCTAD STAT where manufactured goods exporters are categorized into the following fifteen countries or regions: Bangladesh, China, China Hong Kong, Taiwan (Province of China), India, Republic of Korea, Malaysia, Mexico, Morocco, Pakistan, Philippines, Singapore, Thailand, Turkey and Viet Nam. The results may show that all these factors interfere and influence real effects of automatic adjustment mechanisms which in some cases cannot come forth at all. Factors within domestic economic policies that limit the restoration of external balance for these countries/regions thus create an important outcome of this paper.

\section{Time Trend Analysis}

Multiple linear regression models are used to investigate the impacts of variables on the BOPs of manufactured goods exporters. The stability of each variable is tested first for non-smooth inspection process by the unit root inspection process using the ADF method. The multivariate time series models depend on whether there are cointegrating relations among the response series. Johansen cointegration is used to test whether the linear combination of non-smooth sequences has a stable equilibrium relationship, which may be used to modify regression to make it reliable. It is precisely because cointegration conveys a long-term equilibrium relationship that if a reliable link can be found between several variables that appear to have a single randomness trend, the randomness trend brought about by unit roots can be excluded by introducing this "relatively smooth" adjustment of the model. Granger's causality test is then used to analyze whether there is a causal relationship between the variables followed by the multiple regression models. Finally, the impulse response function is used to measure the system's response to a variable being hit.

The multiple linear regression model is established as:

$$
\mathrm{BOP}=\alpha_{0}+\alpha_{1} \mathrm{BOP}_{-1}+\alpha_{2} \mathrm{CPI}+\alpha_{3} \mathrm{GDP}+\alpha_{4} \mathrm{REER}+\alpha_{5} \mathrm{FDI}+\alpha_{6} \mathrm{EX}+\alpha_{7} \mathrm{IM}
$$

where $\mathrm{BOP}_{-1}$ is one-period lag of BOP, CPI is the consumer price index, GDP is gross domestic product, REER is real effective exchange rate, FDI is inflows of foreign direct investment, EX is export, and IM is import of manufactured goods exporters, respectively.

\subsection{Correlation Test}

The variables of manufactured goods exporters are tested first for the correlation. Table 1 shows the seven variables have varying magnitudes of correlation with BOP. Specifically, BOP has moderately positive correlation with CPI (0.7013), FDI (0.7677), EX (0.6879), IM (0.6466) and weaker correlation with REER (0.3418) and GDP (0.1940). 
Table 1. The correlation coefficient analysis.

\begin{tabular}{|c|c|c|c|c|c|c|c|}
\hline Variables & BOP & CPI & GDP & REER & FDI & EX & IM \\
\hline BOP & 1 & & & & & & \\
\hline $\begin{array}{c}\text { CPI } \\
\text { (t-statistics) }\end{array}$ & $\begin{array}{c}0.7013 \\
(4.1734)^{* *}\end{array}$ & 1 & & & & & \\
\hline GDP & $\begin{array}{l}0.1940 \\
(0.8390)\end{array}$ & $\begin{array}{l}0.0444 \\
(0.1885)\end{array}$ & 1 & & & & \\
\hline REER & $\begin{array}{c}0.3418 \\
(1.5429)^{*}\end{array}$ & $\begin{array}{c}0.6307 \\
(3.4483)^{* *}\end{array}$ & $\begin{array}{l}-0.3793 \\
(-1.7390)\end{array}$ & 1 & & & \\
\hline FDI & $\begin{array}{c}0.7677 \\
(5.0835)^{* *}\end{array}$ & $\begin{array}{c}0.9689 \\
(16.6011)^{* *}\end{array}$ & $\begin{array}{l}0.1001 \\
(0.4270)\end{array}$ & $\begin{array}{c}0.6619 \\
(3.7465)^{\text {** }}\end{array}$ & 1 & & \\
\hline EX & $\begin{array}{c}0.6879 \\
(4.0214)^{* *}\end{array}$ & $\begin{array}{c}0.9769 \\
(19.3749)^{* *}\end{array}$ & $\begin{array}{l}0.1022 \\
(0.4360)\end{array}$ & $\begin{array}{c}0.5768 \\
(2.9956)^{* *}\end{array}$ & $\begin{array}{c}0.9692 \\
(16.7075)^{* *}\end{array}$ & 1 & \\
\hline IM & $\begin{array}{c}0.6466 \\
(3.5964)^{* *}\end{array}$ & $\begin{array}{c}0.9615 \\
(14.8486)^{* *}\end{array}$ & $\begin{array}{l}0.1152 \\
(0.4922)\end{array}$ & $\begin{array}{c}0.5359 \\
(2.6928)^{* *}\end{array}$ & $\begin{array}{c}0.9485 \\
(12.7025)^{* *}\end{array}$ & $\begin{array}{c}0.9964 \\
(49.9622)^{* *}\end{array}$ & 1 \\
\hline
\end{tabular}

\subsection{Unit Root Test}

The EViews 10.0 software is used to carry out a stability test on the dependent and independent variables for unit root tests using Augmented Dickey-Fuller (ADF) test forms that might include intercept, time trend, or both items. The lag length is automatically determined according to the AIC/SC information guidelines (Table 2). Tests for unit root are in the $1^{\text {st }}$ difference for all variables as the I (1) process except CPI, that is, the corresponding first-order differential values for most variables are obtained from a smooth process. For CPI, it smoothed out in $2^{\text {nd }}$ difference in unit root test.

Table 2. Unit root test results for all variables.

\begin{tabular}{cccccccc}
\hline variables & $\begin{array}{c}\text { Test type } \\
(\mathbf{C}, \mathbf{T}, \mathbf{K})\end{array}$ & $\begin{array}{c}\text { ADF } \\
\text { statistic }\end{array}$ & $\begin{array}{c}\mathbf{1 \%} \\
\text { level }\end{array}$ & $\begin{array}{c}\mathbf{5 \%} \\
\text { level }\end{array}$ & $\begin{array}{c}\mathbf{1 0 \%} \\
\text { level }\end{array}$ & p-value & result \\
\hline BOP & $(0,0,0)$ & -0.1452 & -2.6924 & -1.9602 & -1.6071 & 0.6204 & $\begin{array}{c}\text { Not stable } \\
\text { Stable }\end{array}$ \\
D(BOP) & $(0,0,1)$ & -3.0721 & -2.6998 & -1.9614 & -1.6066 & 0.0042 & Not stable \\
\hline CPI & $(0,0,0)$ & 12.1033 & -2.6924 & -1.9602 & -1.6071 & 1.0000 & Not stable \\
D(CPI) & $(0,0,1)$ & -0.5744 & -2.7175 & -1.9644 & -1.6056 & 0.4525 & Stable \\
DD(CPI) & $(0,0,2)$ & -5.0957 & -2.7175 & -1.9644 & -1.6056 & 0.0001 & Not stable \\
\hline GDP & $(0,0,0)$ & -0.2982 & -2.6924 & -1.9602 & -1.6071 & 0.5648 & Stable \\
D(GDP) & $(0,0,1)$ & -5.9467 & -2.7081 & -1.9628 & -1.6061 & 0.0000 & Not stable \\
REER & $(0,0,0)$ & 0.5383 & -2.6924 & -1.9602 & -1.6071 & 0.8231 & Stable \\
\hline (REER) & $(0,0,1)$ & -3.6356 & -2.6998 & -1.9614 & -1.6066 & 0.0011 & Not stable \\
FDI & $(0,0,0)$ & 1.6355 & -2.6924 & -1.9602 & -1.6071 & 0.9701 & Stable \\
D(FDI) & $(0,0,1)$ & -3.9082 & -2.6998 & -1.9614 & -1.6066 & 0.0006 & Not stable \\
EX & $(0,0,0)$ & 2.1192 & -2.6924 & -1.9602 & -1.6071 & 0.9886 & Stable \\
\hline (EX) & $(0,0,1)$ & -2.9296 & -2.6998 & -1.9614 & -1.6066 & 0.0059 & Not stable \\
IM & $(0,0,0)$ & 1.5663 & -2.6924 & -1.9602 & -1.6071 & 0.9659 & Stable \\
\hline (IM) & $(0,0,1)$ & -3.1603 & -2.6998 & -1.9614 & -1.6066 & 0.0034 &
\end{tabular}

\subsection{Johansen Co-integration Tests}

Co-integration exists when two variables follow the time-series process of the dependent variable. Unit root tests show that all variables except CPI follow I(1) process, and the Johansen co-integration tests of trace statistic and maximum Eigen statistic are applied in this study. The results are illustrated in Table 3 and 4 and demonstrate that there are at least one co-integrated relationships between these variables. The unit root test of non-equilibrium error is carried out at the same time that the obedience to I(1) process is stable, which further confirms the existence of a co-integration relationship in the sequence. 
Table 3. Johansen co-integration tests (BOP, CPI, FDI, EX, IM).

\begin{tabular}{ccccccc}
\hline $\begin{array}{c}\text { Hypothesized } \\
\text { No. of CE(s) }\end{array}$ & $\begin{array}{c}\text { Trace } \\
\text { Statistic }\end{array}$ & $\begin{array}{c}\text { 5\% Critical } \\
\text { Value }\end{array}$ & Pro. $^{* *}$ & $\begin{array}{c}\text { Max-Eigen } \\
\text { Statistic }\end{array}$ & $\begin{array}{c}\text { 5\% Critical } \\
\text { Value }\end{array}$ & Prob. $^{* *}$ \\
\hline None* & 123.1175 & 69.8189 & 0.0000 & 77.2773 & 33.8769 & 0.0000 \\
At most 1 & 45.8402 & 47.8561 & 0.0764 & 23.1074 & 27.5843 & 0.1689 \\
At most 2 & 22.7328 & 29.7971 & 0.2594 & 17.2209 & 21.1316 & 0.1618 \\
\hline
\end{tabular}

Trace test indicates 1 cointegrating eqn(s) at the 0.05 level

$*$ denotes rejection of the hypothesis at the 0.05 level

**MacKinnon-Haug-Michelis (1999) p-values

Table 4. Johansen co-integration tests (BOP, GDP, REER).

\begin{tabular}{ccccccc}
\hline $\begin{array}{c}\text { Hypothesized } \\
\text { No. of CE(s) }\end{array}$ & $\begin{array}{c}\text { Trace } \\
\text { Statistic }\end{array}$ & $\begin{array}{c}\mathbf{5 \%} \text { Critical } \\
\text { Value }\end{array}$ & Pro. $^{* *}$ & $\begin{array}{c}\text { Max-Eigen } \\
\text { Statistic }\end{array}$ & $\begin{array}{c}\text { 5\% Critical } \\
\text { Value }\end{array}$ & Prob. $^{* *}$ \\
\hline None* & 30.4081 & 29.7971 & 0.0425 & 23.7246 & 21.1316 & 0.0211 \\
At most 1 & 6.6835 & 15.4947 & 0.6147 & 5.6416 & 14.2646 & 0.6595 \\
At most 2 & 1.0420 & 3.8415 & 0.3074 & 1.0420 & 3.8415 & 0.3074 \\
\hline
\end{tabular}

Trace test indicates 1 cointegrating eqn(s) at the 0.05 level

* denotes rejection of the hypothesis at the 0.05 level

**MacKinnon-Haug-Michelis (1999) p-values

\subsection{Granger Causality Tests}

The co-integration tests have demonstrated a long-term equilibrium relationship between the six independent variables of CPI, GDP, REER, FDI, EX, IM and BOP. The Granger's causality tests are then necessary to further verify the relationship between the causes and effects. The Granger causality tests do not hold for CPI, GDP, REER, FDI, EX and IM for BOP for all lagged periods. Despite this result, Granger causality does not imply true causality. If both $\mathrm{X}$ and $\mathrm{Y}$ are driven by a common third process with different lags, their measure of Granger causality could still be statistically significant. Yet, manipulation of one process would not change the other. Indeed, the Granger test is designed to handle pairs of variables, and may produce misleading results when the true relationship involves three or more variables. A similar test involving more variables can be applied with vector autoregression. A new method for Granger causality that is not sensitive to the normal distribution of the error term has been developed by Hacker and Hatemi-J (2006), and is especially useful in financial economics since many financial variables are non-normal.

Table 5. Granger causality tests.

\begin{tabular}{cccc}
\hline Null Hypothesis & F-Statistic & Prob. & Result \\
\hline CPI does not Granger Cause BOP & 1.2947 & 0.3071 & Accept \\
BOP does not Granger Cause CPI & 0.3775 & 0.6929 & Accept \\
GDP does not Granger Cause BOP & 1.3425 & 0.2951 & Accept \\
BOP does not Granger Cause GDP & 0.0428 & 0.9583 & Accept \\
REER does not Granger Cause BOP & 0.2345 & 0.7943 & Accept \\
BOP does not Granger Cause REER & 0.0183 & 0.9819 & Accept \\
FDI does not Granger Cause BOP & 1.0106 & 0.3909 & Accept \\
BOP does not Granger Cause FDI & 0.5386 & 0.5960 & Accept \\
EX does not Granger Cause BOP & 1.6813 & 0.2242 & Accept \\
BOP does not Granger Cause EX & 0.6154 & 0.5554 & Accept \\
IM does not Granger Cause BOP & 1.6892 & 0.2228 & Accept \\
BOP does not Granger Cause IM & 1.2581 & 0.3166 & Accept \\
\hline
\end{tabular}

\subsection{Impulse Response Function Approach}

The impulse response function approach analyses the dynamic response and duration of the explanatory variables when the model is subjected to a shock of one standard deviation from a random error term. The results of the impulse in Figure 1 show that CPI and FDI have a positive impact on BOP with sustained stability 
over time. Its effect has weakened by the $10^{\text {th }}$ phase but can still have a positive impact on the BOP.

The results of the impulse in Figure 2 shows that GDP has a negative impact on BPO in the first 2 phases, a positive impact on BOP from 3 to 7 phases, a negative impact on BOP after that, and a convergence to zero thereafter. The results of the impulse in Figure 2 also shows that REER has a positive impact on BOP in the first 5 phases, a negative impact on BOP after that, and a convergence to zero thereafter.

The results of the impulse in Figure 3 shows that EX has a positive impact on BOP throughout the whole phase and a convergence to zero thereafter. The results of the impulse in Figure 3 also shows that IM has a negative impact on BOP in the first 3 phases, a positive impact on BOP after that, and a convergence to zero thereafter.
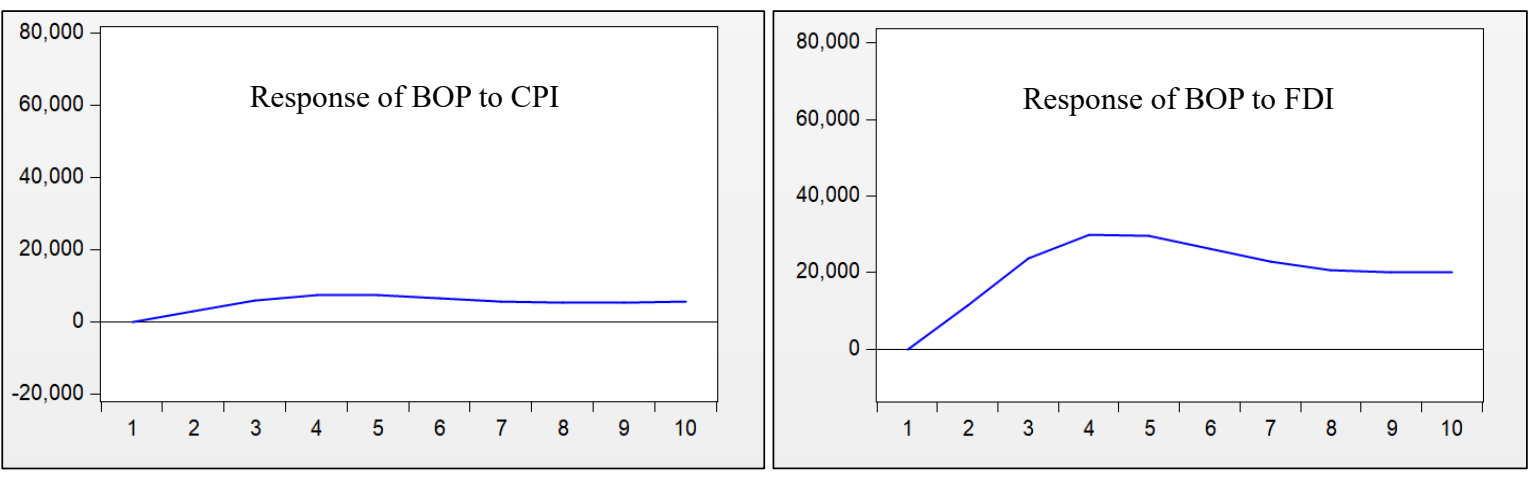

Figure 1. Impulse response of BOP to CPI and FDI.
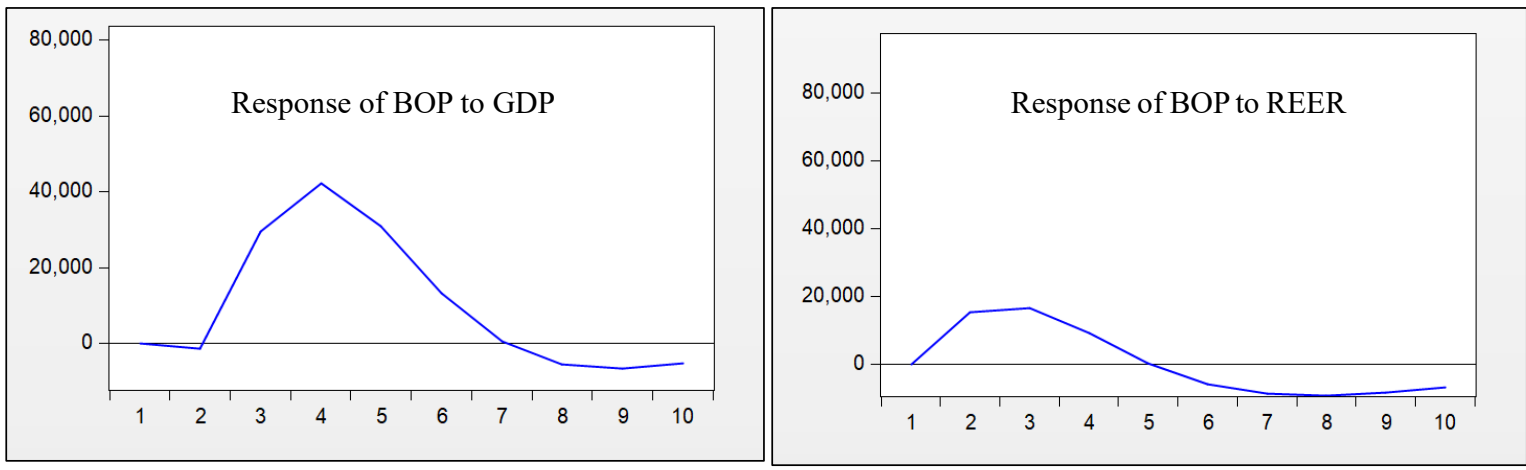

Figure 2. Impulse response of BOP to GDP and REER.
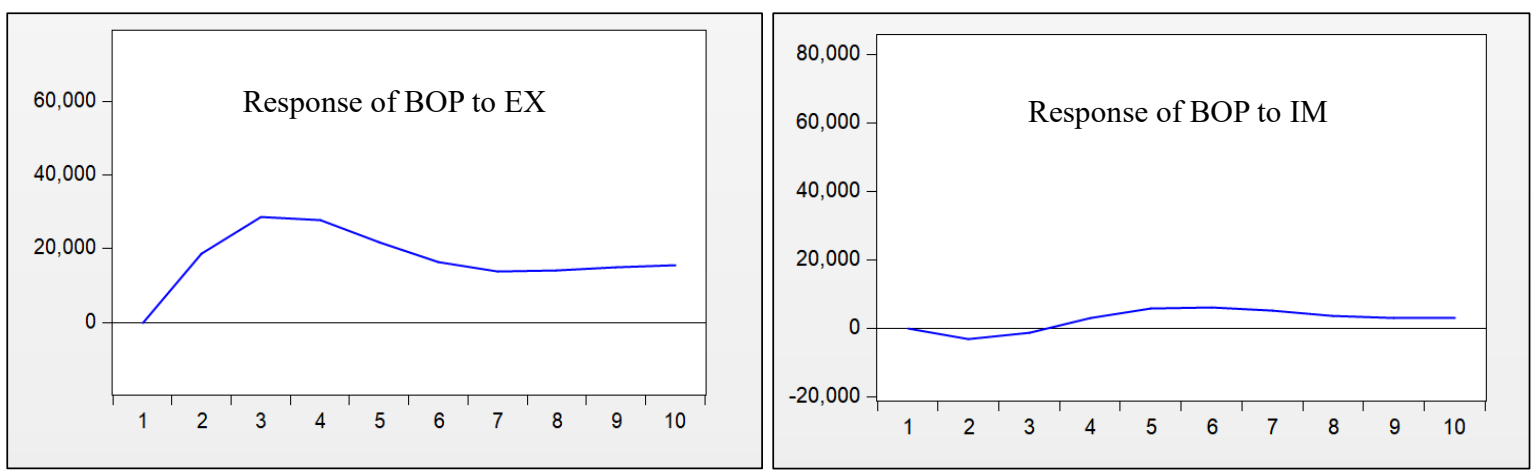

Figure 3. Impulse response of BOP to EX and IM.

\section{Multiple Regression Analysis}

After examining the data above, the following equation is derived in this paper. Both the original equation and the logarithm-form equation are estimated and the results are shown in Table 6. The logarithm-form model results show that lagged BOP accounts for $2.58 \%$ of the effects on current BOP, a relatively lower one. Most of the variables present the anticipated signs except FDI, which has negative impact on BOP with a nearly unit elasticity. Among all effects, the export effect dominates with the elasticity of 19.2320 followed by the import 
effect of with the elasticity of -16.1699 . The effect of exchange rate ranks the third on the impact to BOP for manufactured good exporters with the elasticity of -3.8121 , followed by the effect of price with the elasticity of -2.6553 and the effect of income with the elasticity of -0.4361 .

In both equations, the coefficients of LOG (FDI) do not match the results obtained from the principle and LOG (FDI) should be positive. According to the final results, the impact of LOG (FDI) on LOG (BOP) is negative. That is, for manufactured exporters, each additional unit of FDI decreases the balance of payments by $58.93 \%$, holding other volumes constant. The 15 exporters of manufactured goods are all developing countries, and for which the local market structure is immature and unstable so that without the protection of good national policies, FDI would destabilize their capital markets and be detrimental to their economic development and balance of payments. Moreover, among these 15 countries, China accounts for a large proportion of manufacturing exports and can be a representative of these 15 countries, and also contributes considerably to the direction of the conclusions of this paper. China is very typical of a country with sufficient labor but not sufficient capital, and it can be said that the difference between labor and capital is particularly large. When foreign capital flows in, it can initially make up for the lack of capital. If more foreign capital is absorbed, it can lead to a serious imbalance in the balance of payments because China is in a phase of rapid economic growth and has not yet developed a complete financial system, plus the country is also facing such rapid economic growth for the first time, it will not be able to react and its policies will not be able to keep up with the growth of the economy. This is the equivalent of China's perennially excessive surplus prior to the 2008 financial crisis, and also a perfect illustration of the Mead conflict, with severe inflation and the inability of state policy to smooth out the balance of payments. The best policy to deal with the impact of FDI is a managed floating exchange rate system that responds to the impact of foreign capital by means of state regulation until the national economic system is stabilized.

Table 6. Multiple linear regression results.

\begin{tabular}{ccccc}
\hline & \multicolumn{3}{c}{ Model } & \multicolumn{2}{c}{ LOG(Model) } \\
\hline C & $1,796,757$ & $1,632,312$ & 15.4436 & $(1.0095)$ \\
(t-statistics) & $(4.0385)^{* *}$ & $(2.4253)^{*}$ & $(2.1199)^{*}$ & 0.0258 \\
BOP $_{-1}$ & & 0.3020 & & $(0.1215)$ \\
& & $(1.1675)$ & -2.6553 \\
CPI & $-6,706.89$ & $-13,007.64$ & -0.7455 & $(-1.4174)$ \\
& $(-1.8930)$ & $(-2.7113)^{*}$ & $(-0.6511)$ & -0.4361 \\
GDP & $-8,632.14$ & $-9,280.19$ & -0.1088 & $(-1.1309)$ \\
& $(-0.7366)$ & $(0.6095)$ & $(-0.3834)$ & -3.8121 \\
REER & $-13,698.97$ & $-8,303.09$ & -4.8345 & $(-1.7861)$ \\
& $(-3.8509)^{* *}$ & $(-1.3944)$ & $(-3.2246)^{* *}$ & -1.0702 \\
FDI & 0.5538 & -0.8268 & -0.5330 & $(-1.4289)$ \\
& $(0.6795)$ & $(-0.7164)$ & $(-0.9371)$ & 19.2320 \\
EX & 0.9201 & 1.2659 & 16.1818 & $(4.8257)^{* *}$ \\
& $(3.2331)^{* *}$ & $(3.8086)^{* *}$ & $(6.3482)^{* *}$ & -16.1699 \\
IM & -0.8135 & -1.0212 & -14.2233 & $(-4.9625)^{* *}$ \\
\hline R & $(-3.7310)^{* *}$ & $(-4.1525)^{* *}$ & $(-6.4554)^{* *}$ & 0.9323 \\
Adj. R & 0.8827 & 0.9064 & 0.9261 & 0.8892 \\
D-W & 0.8286 & 0.8469 & 0.8919 & 2.2379 \\
\hline
\end{tabular}

\section{Conclusion}

For manufactured exporters, FDI does not play a significant role in the BOP of exporters of manufactured goods compared to other variables. On the contrary, evidence from the Granger causality test demonstrates that exports are the cause of FDI. This proves that FDI does not have a positive impact for these 15 developing manufactured exporters, which is not in line with the general picture although the impact of FDI on BOP is also negative in some individual country studies. This may be due to the fact that the impact of FDI changes over time, or because for these developing countries they all use a floating exchange rate regime.

Automatic balance-of-payments adjustment refers to the reaction of changes in domestic economic 
variables caused by balance-of-payments imbalances to the balance of payments. In a complete or nearcomplete market economy, the balance of payments can be automatically restored to balance through the adjustment of market economy variables. Of course, automatic balance-of-payments adjustment can only have the theoretically described effect in a purely free economy, and government macroeconomic policies can interfere with the process of automatic adjustment by causing it to diminish, distort or not work at all.

In the use of policies to adjust the balance of payments, we should not ignore the total supply of industrial policies, science and technology policies and institutional innovation policies. These policies aim to improve a country's economic structure and industrial structure, improve labor productivity, increase the production of exported goods and services, improve product quality and reduce production costs so as to increase the supply of social products and improve the balance of payments. In fact, the exact policy of a government to regulate the balance of payments depends first on the nature of the balance of payments imbalance, secondly on the domestic social and macroeconomic structure of the balance of payments imbalance, and again on the interrelationship between internal and external balances. Each balance of payments adjustment policy will bring more or less adjustment costs to the macro-economy. It is necessary to make camera choices using various policies with the lowest economic and social costs to achieve balance of payments, and the right policy mix is the core of successful balance of payments adjustment.

Governments often adjust their balance of payments in the interests of their own countries, and the relevant adjustment measures may adversely affect other countries, leading to corresponding retaliatory measures by other countries. In order to maintain the normal order and operation of the world economy and finance, it is necessary for governments of manufactured good exporters to strengthen the international coordination of balance of payments adjustment policies and to determine the general principles of balance of payments adjustment through various international economic agreements. At the same time, it is better to employ economic and financial liberalization as the core to restrict countries to adopt self-interest adjustment policies to ease the contradictions between countries. International financial organizations or international agreements could better provide financial facilities to countries with balance-of-payments deficits in order to alleviate their international liquidity shortfalls. In addition, regional economic integration groups have been established to promote regional economic and financial integration and balance-of-payments adjustment in order to alleviate balance-of-payments imbalances among member countries through relevant policy coordination.

\section{References}

1. Ali, S. A., Zia, S. A., \& Razi, A. (2012). Impact of Foreign Direct Investment and Worker's Remittances on Balance of Payment: A Case Study of Pakistan. Global Journal of Management and Business Research, 12(22): 37-42.

2. Ahluwalia, M. S. (1986). Balance-of-payments Adjustment in India, 1970-1971 to 1983-1984. World Development, Elsevier, 14(8): 937-962.

3. Bird, G. (1982). Balance-of-payments Adjustment in LDCs. Palgrave Macmillan, UK.

4. Bulmerthomas, V. (1987). The Balance-of-Payments Crisis and Adjustment Programmes in Central America. Palgrave Macmillan, UK.

5. Cazacu, S. (2016). Contemporary Theoretical and Methodological Aspects Regarding Foreign Direct Investment between Moldova and Greece. Studia Universitatis Moldaviae, 2(92): 182-187.

6. Chidoko, C., \& Sakuhuni, R. C. (2015). An Analysis of the Impact of Foreign Direct Investment Inflows on the Balance of Payments of Zimbabwe. Global Journal of Advanced Research, 2(4): 742-748.

7. Connors, T. A. (1979). Balance-of-payments Adjustment in the West African Monetary Union (Unpublished Ph.D Thesis). Ann Arbor: University of Michigan.

8. Dai, L. (2020). The Empirical Analysis of the Influence of RMB Real Effective Exchange Rate to Chinese Balance of Payment. World Scientific Research Journal, 6(4): 16-24.

9. Gong, Y. Y. (2019). Study on the Impact of Foreign Direct Investment on China's Balance of Payments (Unpublished Master's Thesis). Jilin: Jilin University of Finance and Economics.

10. Hacker, R. S., \& Hatemi-J, A. (2006). Tests for Causality between Integrated Variables Using Asymptotic and Bootstrap Distributions: Theory and Application. Applied Economics, Taylor \& Francis Journal, 38(13): 1489-1500.

11. Hailu, Z. A. (2010). Impact of Foreign Investment on Trade of African Countries. International Journal of Economics and Finance, 2(3): 122-133.

12. Han, W. Y., Xiong, Y. L., \& Zhang, Z. Q. (2021). Evolution Characteristics and Enlightenment of American Manufacturing Industry since the 21st Century, World Sci-Tech R \& D, 1-18.

13. Hansen, H., \& Rand, J. (2005). On the Causal Links between FDI and Growth in Developing Countries. Research 
Paper No. 2005/31, Tokyo: United Nations University.

14. Hirad, A., Karbasaki, M. M., \& Hirad, S. (2013). Study of the Effects of FDI Inflow on Balance Payment. Journal of Basic and Applied Scientific Research, 3(92): 690-697.

15. Hnát, P., \& Jiránková, M. (2012). Balance of Payments Adjustment Mechanisms in the Euro Area. Eastern Journal of European Studies, 3(1): 67-86.

16. Hou, H. X. (2019). Real Effective Exchange Rate of RMB, International Balance of Payment and Economic Growth (Unpublished Master's Thesis). Anhui: Anhui University of Finance \& Economics.

17. Li, W. (2020). Research on Influencing Factors of Changes in Chinese Balance of Payments (Unpublished Master's Thesis). Liaoning: Liaoning University.

18. Micossi, S. (2016). Balance-of-Payments Adjustment in the Eurozone, CEPS Papers 11250, Centre for European Policy Studies.

19. Paldam, M. (1990). The Socio-Political Reactions to Balance-of-Payments Adjustments in LDCs: A Pilot Study: The Case of Chile 1982.

20. Plessis, S. D. (1987). Balance of Payments Adjustment: Monetary and Fiscal Policies. In International Economics. Oxford: Butterworth-Heinemann Elsevier Ltd.

21. Rahman, M. N. (2016). Impact of Foreign Investment Inflows on Capital Account of India's Balance of Payment. Business and Economic Research, 6(1): 111-128.

22. Stoever, W. A. (2000). Differentiating Extractive, Manufacturing and Service Investments in LDCs. Review of Business, 21(1/2): 23-23

23. Yabs, J. (2018). Foreign Direct Investment and Balance of Payment in Kenya. European Journal of Business and Management, 10(30): 29-32.

24. Yang, G. L., \& Lin, F. Y. (2021). Verification of Double Surplus and Balance of Payments. Journal of Business Innovation, 3(2): 97-105.

25. Yang, G. L., Zhang, Y., Jiang, Y. X., \& Zhuang, S. Q. (2021). Driving Force of Effective Exchange Rate Fluctuation and Verification of Balance of Payments. Journal of Business Innovation, 3(1): 16-22.

(Editor: Xiaoxuan Liu) 